\title{
PENGETAHUAN TENTANG SADARI PADA PASIEN KANKER PAYUDARA (CAMAMMAE) DI RUMAH SAKIT UMUM PUSAT SANGLAH DAN RUMAH SAKITPRIMA MEDIKA BALI NOVEMBER 2012
}

\author{
I Made Sindhu Satya Nugraha ${ }^{1}$, Ni Made Suari Utami ${ }^{1}$, Yudo Affandi ${ }^{1}$, Gede Wara Samsarga ${ }^{1}$, I. B. Tjakra \\ Wibawa Manuaba² \\ ${ }^{1}$ Program Studi Pendidikan Dokter Fakultas Kedokteran Universitas Udayana Denpasar \\ ${ }^{2}$ Sub-Bagian Bedah Onkologi, Bagian SMF IImu Bedah, Rumah Sakit Umum Pusat Sanglah, Fakultas Kedokteran \\ universitas Udayana, Denpasar, Bali \\ (gnt000@yahoo.com)
}

\begin{abstract}
ABSTRAK
Salah satu pemeriksaan dini untuk mengetahui kanker payudara adalah dengan sadari (periksa payudara sendiri). Dengan melakukan sadari, pasien akan dapat mengetahui jika terdapat benjolan atau sesuatu yang tidak normal. Sadari dapat di lakukan sendiri setelah selesai mandi dengan berdiri di depan cermin.Penelitian di lakukan di 2 rumah sakit di kota Denpasar untuk mendapatkan deskripsi mengenai pengetahuan pasien kanker payudara tentang sadari. Hasil yang di dapatkan dari 30 sampel kanker payudara adalah 4 pasien (13,3\%) kanker payudara tahu tentang sadari. Kemudian dari 4 pasien kanker payudara yang tahu tentang sadari, 2 pasien $(50 \%)$ pernah melakukan sadari. Sisa sampel yang berjumlah 26 pasien $(86,7 \%)$ tidak tahu tentang sadari. Informasi tentang sadari di sendiri dapat dari keluarga atau teman yang pernah mengidap kanker payudara. Pasien-pasien yang mendapatkan kelainan dari pemeriksaan sadari biasanya tidak langsung datang kerumah sakit, melainkan di biarkan sehingga datang dalam keadaan yang buruk.
\end{abstract}

Kata Kunci : sadari, kanker, payudara

\section{Knowledge about SADARI in Breast Cancer (Ca Mammae)Patient in Sanglah Hospital}

\section{ABSTRACT}

One of theearly inspectionto determinebreastcanceris sadari (periksa payudara sendiri). By doing sadari,patients will beable to knowifthere is alumporsomething that isabnormal. Sadarican be donealoneafter showerby standing infront of the mirror. Researchconducted in2 hospitalsin Denpasartogeta description of thepatient's knowledgeaboutbreastcancer.Resultsin gettingfrom 30breast cancer sampleswere4 patients(13.3\%) breast cancer knowaboutsadari. Thenfrom 4breastcancerpatientsknowaboutsadari, 2 patients(50\%) didsadari.The remainingsample of 26 patients(86.7\%) did not know aboutsadari. They got information aboutsadarifromfamily orfriends who'vehad breast cancer. Patientswho foundabnormalities from the examinationare usually notcameto the hospital, butthey didn't care about it,socomein a bad state.

Keywords: sadari, cancer, breast

\section{PENDAHULUAN}

Kanker merupakan penyakit yang ditandai dengan adanya perubahan sel yang menyebabkan pembelahan sel yang tidak stabil, menyerang sel biologis didekatnya, dan dapat bermigrasi ke jaringan tubuh lainnya (metastasis) ${ }^{3}$. Penyebab kanker hingga saat ini belum dapat dipastikan, namun terdapat beberapa faktor resiko yang dapat menyebabkan kanker seperti faktor lingkungan (90\%-95\%) dan faktor genetik (5\%-10\%). Faktor lingkungan antara lain : bahan kimia (karsinogen), radiasi, dan infeksi (Human Pappiloma Virus). Banyak terdapat jenis kanker antara lain: kanker paru, kanker kolorektal, gastrointestinal kanker, kanker payudara, dII. ${ }^{1}$

Tumor dapat diklasifikasikan menjadi noninvasif dan invasif, dan sebagian besar (76\%) adalah ductal breast cancer yang invasif. Salah satu kanker yang paling banyak ditemui adalah kanker payudara. Kanker payudara paling banyak terdapat pada wanita pada negara berkembang dan tingkat mortalitasnya sekitar $20 \%$ dari keseluruhan kanker. Di UK (United Kingdom), terdapat 40.707 kasus kanker payudara yg terdiagnosis pada tahun 2000. 240 kasus pada pria $(0,6 \%)$ dan terjadi 12.925 kasus kematian akibat dari kanker payudara. ${ }^{2}$

Insiden kanker payudara meningkat seiring dengan umur, tingkat terpapar dengan estrogen, tingkat status socioekonomi yg tinggi, tingkat eksposur dengan radiasi, riwayat keluarga dan faktor predisposisi yang lain. ${ }^{2}$ Beberapa faktor resiko yang berhubungan dengan perkembangan penyakit ini adalah merokok, konsumsi alkohol, umur saat menarche, dan umur saat melahirkan anak pertama. Kanker dapat di-staging menggunakan karakteristik klinis dari diameter tumor (T), adanya 
penyebaran pada lymph node $(\mathrm{N})$, dan adanya tanda metastasis yang jauh (M), ${ }^{1}$ dan khusus untuk kanker payudara dapat diketahui melalui program SADARI (periksa payudara sendiri) dan mammography.

SADARI sendiri adalah suatu cara untuk deteksi dini kanker payudara dan dapat dilakukan dengan mudah oleh orang itu sendiri. Biasanya sadari dilakukan setelah mandi dan di depan cermin dengan cara memperhatikan bentuk, ukuran, dan gerakan kedua payudara, dan menekan payudara untuk mengetahui adanya massa atau benjolan.

\section{METODE DAN BAHAN}

Penelitian dilakukan di Rumah Sakit Umum Pusat Sanglah dan Rumah Sakit Prima Medika pada tanggal 7-12 November 2012. Desain studi deskriptif digunakan pada penelitian ini untuk mengetahui pengetahuan pasien kanker payudara tentang sadari. Pasien akan diwawancara dan hasilnya akan dicatat pada kuisioner yang telah disiapkan. Sampel yang dipakai pada penelitian ini adalah pasien kanker payudara di dua rumah sakit ini.Pasien kanker payudara di tempat penelitian merupakan pasien yang telah terdiagnosis berdasarkan anamnesis, pemeriksaan fisik, imaging, dan diagnosis pasti berdasarkan pemeriksaan histopatologis. Data didapatkan dengan menggunakan metode kuisioner. Kemudian datadata penelitian dianalisis secara deskriptif dan hasilnya ditampilkan dalam bentuk diagram lingkar.

\section{HASIL}

Dari data penelitian yang didapatkan di Rumah Sakit Umum Pusat Sanglah dan Rumah Sakit Prima Medika didapatkan 38 pasien, 30 pasien merupakan pasien kanker payudara. Dari hasil wawancara dengan menggunakan metode kuisioner, didapatkan bahwa 4 pasien $(13,3 \%)$ mengetahui dan pernah mendengar tentang SADARI sedangkan sisanya 26 pasien $(86,67 \%)$ tidak mengetahui dan tidak pernah mendengar tentang SADARI.

\section{PASIEN TAHU SADARI}

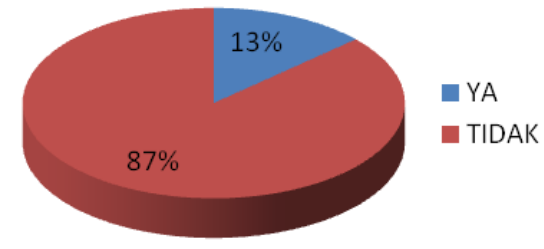

Gambar 1. Persentase Pasien yang Tahu Tentang SADARI.

\section{Pasien pernah sadari}

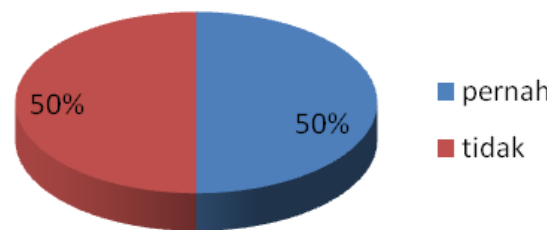

Gambar 2 Persentase Pasien yang Pernah SADARI dari Pasien yang Tahu Tentang SADARI.

Sedangkan dari 4 pasien yang tahu tentang SADARI, sekitar $50 \%(n=2)$ yang pernah atau rutin melakukan SADARI.

Dari 26 pasien yang tidak tahu dan tidak pernah mendengar SADARI, terdapat $4(15,3 \%)$ pasien yang pernah melakukan SADARI. Mereka tidak pernah tahu atau mendengar istilah SADARI dan mendapatkan info tentang pemeriksaan payudara dari saudara atau teman yang mengalami kanker payudara.

\section{Pasien pernah sadari}

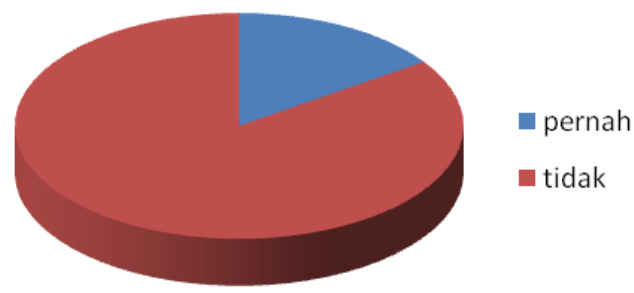

Gambar3. Persentase Pasien yang Pernah SADARI dari Pasien yang Tidak Tahu Tentang SADARI.

\section{PEMBAHASAN}

Dari hasil penelitian di atas menunjukkan bahwa sekitar $13,3 \%$ ( 4 pasien) dari pasien kanker payudara yang tahu tentang SADARI dan sisanya $86.7 \%$ (26 pasien) tidak tahu tentang SADARI. Sedangkan pasien yang rutin melakukan SADARI dari yang tahu tentang SADARI hanya 2 pasien (50\%). Ini menunjukkan kurangnya sosialisasi dan pengetahuan pasien tentang SADARI.

Hasil wawancara menunjukkan kurangnya pengetahuan pasien tentang gejala dan tanda dari kanker payudara sehingga mereka membiarkan benjolan yang ada sehingga menjadi semakin besar dan menjadi stadium yang lebih lanjut. ${ }^{4}$

\section{SIMPULAN}


Rendahnya pengetahuan pasien kanker payudara tentang SADARI menunjukkan kurangnya informasi dan sosialisasi yang didapatkan oleh masyarakat. Laporan ini masih memerlukan waktu yang panjang sehingga akan menjadi lebih akurat dan lebih baik sehingga mendapatkan pasien lebih banyak dan kuisioner yang lebih baik.

\section{SARAN}

Setelah melihat hasil dari data di atas, kurangnya pengetahuan tentang SADAkRI pada pasien kanker menunjukkan rendahnya informasi yang diperoleh oleh pasien sehingga pasien datang ke rumah sakit dengan keadaaan yang buruk. Pihak - pihak yang terkait mungkin harus lebih gencar melaksanakan sosialisasi dan membuat program tentang SADARI kepada masyarakat.

\section{DAFTAR PUSTAKA}

1. Macdonald.F, Ford C.H.J. Molecular biology of cancer.Bios Scientific Publishers 1997; 117-128.

2. Barber matthew D, Thomas Jeremy St .j, Dixon J Michele. An atlas of investigation and management breast cancer. 2006; 45-48.

3. WHO. Media Centre. 2012. Avaible from [http://www.who.int/mediacentre/factsheets/fs297/e n.]. Accessed November 8, 2012.

4. Affandi Yudo, Utami NM Suari, Samsarga G Wara, Nugraha IMSS. Keterlambatan Pasien Kanker Payudara dan Kanker Kolorektal Mencari Pengobatan Konvensional Akibat Persepsi Negatif terhadap Tindakan Pembedahan di Rumah Sakit di Kota Denpasar, Bali. 2012. 